\title{
Drilling disturbance and constraints on the onset of the Paleocene-Eocene boundary carbon isotope excursion in New Jersey
}

\author{
P. N. Pearson ${ }^{1}$ and E. Thomas ${ }^{2,3}$ \\ ${ }^{1}$ School of Earth and Ocean Sciences, Cardiff University, Cardiff CF10 3AT, UK \\ ${ }^{2}$ Department of Geology and Geophysics, Yale University, New Haven, CT 06520-8109, USA \\ ${ }^{3}$ Department of Earth \& Environmental Sciences, Wesleyan University, Middletown, CT 06459, USA \\ Correspondence to: P. N. Pearson (pearsonp@ cardiff.ac.uk)
}

Received: 14 July 2014 - Published in Clim. Past Discuss.: 13 August 2014

Revised: 1 December 2014 - Accepted: 9 December 2014 - Published: 16 January 2015

\begin{abstract}
The onset of the Paleocene-Eocene thermal maximum (PETM) and associated carbon isotope excursion (CIE; approx. 56 Mya) was geologically abrupt, but it is debated whether it took thousands of years or was effectively instantaneous. Wright and Schaller (2013) published a significant new record of the onset of the CIE, and claimed that it could be resolved across 13 annual layers in a drill core through the Marlboro clay at Millville, New Jersey (Ocean Drilling Program (ODP) Leg 174X). Supporting evidence for similar layering was reported from another New Jersey drill site, Wilson Lake B, and a photograph of the Marlboro clay in outcrop (Wright and Schaller, 2014). Such a short duration would imply an instantaneous perturbation of the atmosphere and surface ocean and the impact of a comet or asteroid as the likely cause. However, Pearson and Nicholas (2014) suggested, based on the published core photographs, that the layers in the Marlboro clay cores could be artifacts of drilling disturbance, so-called biscuiting, wherein the formation is fractured into layers or biscuits and drilling mud is injected in between the layers. (We now prefer the term core discing following Kidd, 1978.) Here we report new observations on the cores which support that interpretation, including concentric grooves on the surfaces of the core discs caused by spinning in the bit, micro-fracturing at their edges, and injected drilling mud. We re-interpret the limited outcrop evidence as showing joints rather than sedimentary layers. We argue that foraminifer concentrations in the sediments are far too high for the layers to have been annually deposited in turbid waters at depths of $40-70 \mathrm{~m}$, indicating that the onset of the CIE in the Marlboro clay likely took on the order of millennia, not years (Zeebe et al., 2014). Re-coring of Millville
\end{abstract}

aimed at minimizing drilling disturbance to allow a higherresolution study of the carbon isotope excursion is highly desirable.

\section{Introduction}

The Paleocene-Eocene boundary is one of the most intensively studied intervals of abrupt climate change in Earth's past (Kennett and Stott, 1991; Thomas and Shackleton 1996; Zachos et al., 2005). Its main features are a pronounced global warming spike of over $5^{\circ} \mathrm{C}$ (Paleocene-Eocene thermal maximum, PETM), which happened in an already warm world, associated with carbonate dissolution and a negative carbon isotope excursion (CIE) of at least several parts per thousand that persisted and then decayed over approximately $200 \mathrm{ka}$ (Sluijs et al., 2007b; Dunkley Jones et al., 2010; McInerney and Wing, 2011; Aze et al., 2014). All attempts at explaining the event involve the addition of large amounts of isotopically light carbon to the exogenic carbon pool. Non-exclusive possibilities include volcanic emissions (Eldholm and Thomas, 1993; Bralower et al., 1997; Storey et al., 2007), the mobilization and oxidation of seafloor methane from clathrates (Dickens et al., 1995; Katz et al., 1999), emission of thermogenic methane from deeply buried hydrocarbons after igneous intrusion (Kurtz et al., 2003; Svenson et al., 2004), oxidation of organic-rich sediments in epicontinental seas (Higgins and Schrag, 2006), release of dissolved carbon compounds from stratified marine basins (Nisbet et al., 2009), runaway release of methane from rapidly melting permafrost (Deconto et al., 2012), combustion of part of the 
biosphere (Huber, 2008), and extraterrestrial carbon dumped by a comet, the impact of which could have triggered further methane release (Kent et al., 2003; Cramer and Kent, 2005; Wang et al., 2013). Most stratigraphic records indicate a geologically rapid onset, but that definition could mean any duration between approx. 20 thousand years (Cui et al., 2011) and a few thousand years (e.g., Kennett and Stott, 1991; Thomas et al., 2002; Zachos et al., 2005, 2007; Aziz et al., 2008a) or just a few years, i.e., effectively instantaneous (Kent et al., 2003; Cramer and Kent, 2005). Resolution of this question will provide constraints on the likely source of the carbon and advance our understanding of disturbances of Earth's carbon cycle and their effect on ocean chemistry and life.

Although hitherto a minority view, an instantaneous onset of the PETM and associated CIE would have profound implications for our understanding of the event. For example, it would have caused sudden and substantial acidification of the upper layers of the ocean in contact with the atmosphere, whereas a slower rate of carbon release would have caused a less sharp acidification response because shallow and surface waters are continually mixed into the much larger deep ocean reservoir on timescales of the circulation of the deep ocean, i.e., millennia (Ridgwell and Schmidt, 2010; Hönisch et al., 2012). There was no mass extinction of calcareous plankton (Gibbs et al., 2006; Zachos et al., 2006, 2007; Bown and Pearson, 2009; Self-Trail et al., 2012) or shallow-water smaller benthic foraminifera (Gibson et al., 1993; Stassen et al., 2012) at the Paleocene-Eocene boundary; hence, a quasiinstantaneous onset to the event would imply that these organisms adapted to rapid acidification. More generally, the lack of a global mass extinction on land and in the oceans (except among deep-sea benthic foraminifera) would indicate unexpected, and perhaps reassuring, resilience of life to profound and abrupt global warming (e.g., Thomas, 2004; McInerney and Wing, 2011).

\section{Previous discussion}

Significant new evidence relating to the pattern and timing of the CIE onset was presented by Wright and Schaller (2013) from a drill site at Millville, New Jersey (Ocean Drilling Program (ODP) Leg 174X; Sugarman et al., 2005). Their data show one of the clearest and best-resolved onsets yet published (reproduced here as Fig. 1) with a run of intermediate bulk sediment $\delta^{13} \mathrm{C}$ values showing a somewhat stepped appearance, including intervals of little change or possibly even reversals in the trend. Critically, Wright and Schaller (2013) described the Marlboro clay formation at Millville and the nearby Wilson Lake B core (as yet unpublished, but a re-drill of a Wilson Lake core studied at high resolution by Gibson et al., 1993, Zachos et al., 2006, Gibbs et al., 2006, Sluijs et al., 2007a, and Stassen et al., 2012b) as "characterized by rhythmic couplets of silty kaolinitic clay distinguished by 1 to $2 \mathrm{~mm}$ layers of swelling smectite clays and micaceous silt,

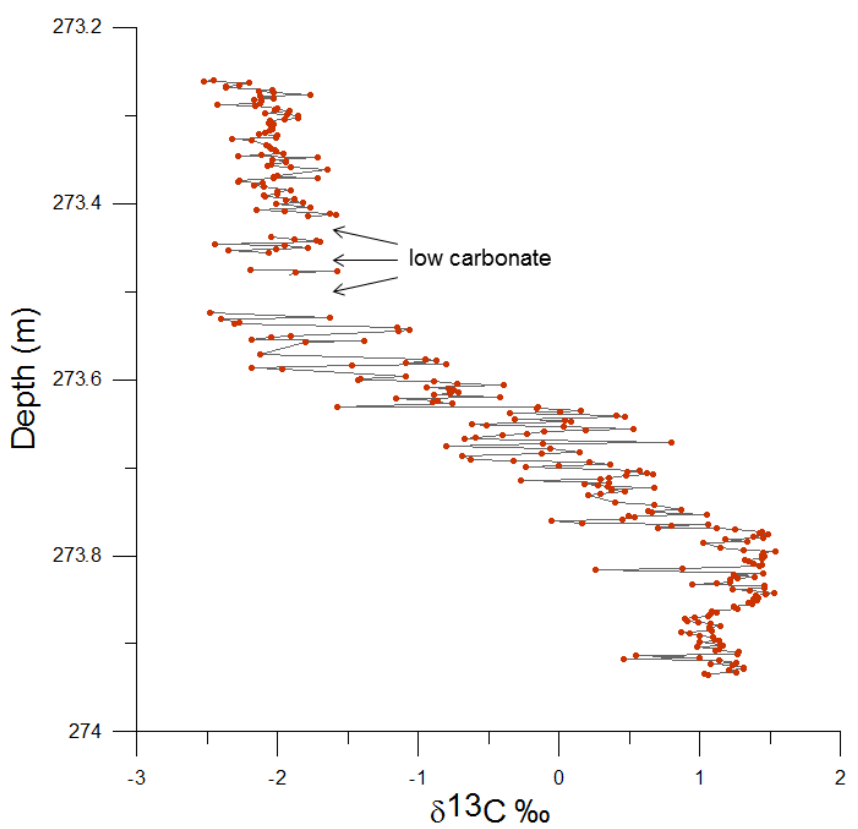

Figure 1. Onset of the carbon isotope excursion at Millville, New Jersey (data replotted from Wright and Schaller, 2013).

recurring every $1-3 \mathrm{~cm}$ through the entirety of the unit". They referred to similar layers in the same formation in the nearby Ancora core (ODP Leg 174X; Harris et al., 2010), the South Dover Bridge core (Maryland, Self-Trail et al., 2012), and an exposure at Medford, the latter without citation. At Millville they counted $\sim 750$ such couplets over approximately $12.5 \mathrm{~m}$ of Marlboro clay, with just 13 couplets spanning the CIE onset, potentially providing a precise duration.

The interpretation that the couplets are annual rests first on demonstrating that they are seasonal in origin. Wright and Schaller (2013) argued for this partly on the sedimentology (especially the rhythmicity of the layering), and partly on the basis of a high-resolution bulk oxygen isotope record through two sections (approximately 25 and $10 \mathrm{~cm}$, respectively) of the Wilson Lake B core. These sections were claimed to show cyclic variability in $\delta^{18} \mathrm{O}$ values, with maxima corresponding to the thin smectitic layers. The variability was interpreted as corresponding to temperature and/or salinity fluctuations. Wright and Schaller (2013) rejected the possibility of an orbital control or other long-period cycles because the Marlboro clay lies entirely within magnetochron C24r (which has a duration of 2.6 Myr; Cande and Kent, 1995). Therefore, they proposed that the couplets must be annual and the variability seasonal, arguing that the implied very rapid sedimentation rate $(1-3 \mathrm{~cm} / \mathrm{yr})$ is within the bounds of measured rates in fast-depositing mud-belt areas of modern shelf regions, e.g., close to the Amazon River outflow. If the CIE onset occurred in just 13 years in the sediment, the atmospheric perturbation would have been effectively instantaneous which rules out all of proposed sources of carbon 
as significant contributors to the CIE onset except for a comet impact or possibly emissions from massive volcanism (Wright and Schaller, 2013).

These claims elicited responses from Pearson and Nicholas (2014) who argued that the supposed annual layers were artifacts of drilling disturbance; from Stassen et al. (2014), who argued that the estimated paleodepths were too shallow, and included the argument that planktonic foraminiferal assemblages could not have been deposited in as little as 13 years; and from Zeebe et al. (2014) who argued against an instantaneous event based on geochemical modeling.

\section{Core discing}

There are many ways in which a rock or sediment can be disturbed during the drilling process, depending on the type of coring (e.g., rotary versus piston coring) and the mechanical properties of the formation. Drilling disturbance encompasses various types of plastic and brittle deformation, and the effects can vary from subtle to severe. Core discing (or biscuiting) is a form of drilling disturbance that occurs when the torque induced by rotary drilling is transferred to the sedimentary formation as it enters the core barrel, inducing repetitive mechanical failure (Kidd, 1978; Leggett, 1982; Graber et al., 2002; Hubbard, 2007). It was frequently encountered when rotary coring of sediments was the norm during the days of the Deep Sea Drilling Project (DSDP). The first detailed description was made by Kidd (1978) on DSDP Leg $42 \mathrm{~A}$, who found that cores:

... are found to be broken horizontally into pieces. At the breaks, the upcore surfaces of the pieces are convex while the undersurface of those above are concave. This is the result of the individual pieces rotating upon one another inside the core barrel as the core is being cut. Often, the break is along a change in lithology such as a sandy horizon or a silt or shell lamina, although just as frequently no lithological change is apparent. ...This is referred to as core discing, a process familiar to rig geologists in the drilling industry, and is found when weight on the bit required to core stiff lithologies (especially waxy clays) causes a hammer or bounce effect. (Kidd, 1978, 1133-1134)

It is not clear to us whether a hammer effect is necessary to induce core discing, but we reproduce the suggestion from Kidd (1978) for consideration. An example of a core disturbed in this way is reproduced from Kidd (1978) in Fig. 2a, including an illustration of the concentric grooves on the upper and lower surfaces of the core discs caused by spinning and abrasion in the core barrel. Kidd (1978) also described micro-faulting as a common kind of drilling disturbance in the same cores.
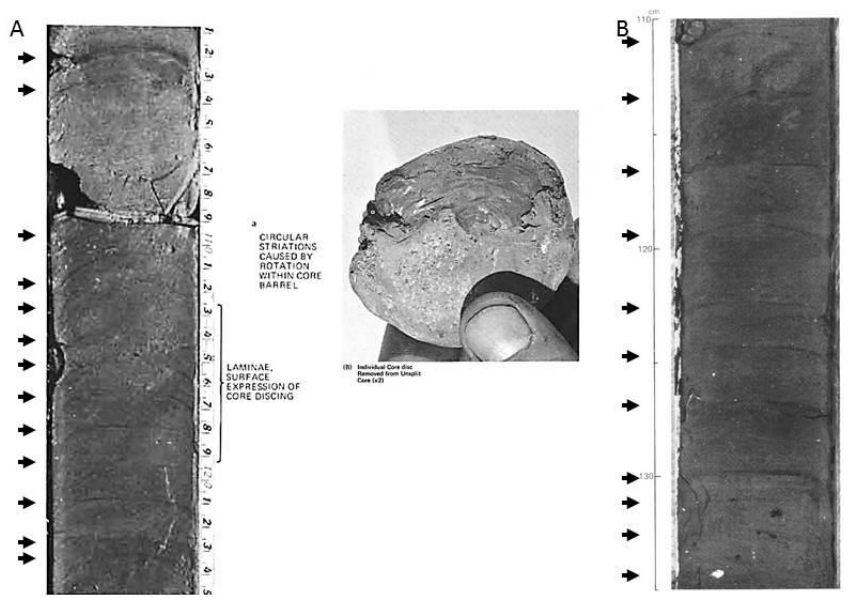

Figure 2. (a) "Core discing" as illustrated by Kidd (1978) from DSDP Site 376 (Florence Rise, Mediterranean Sea west of Cyprus). (b) "Drilling laminations" illustrated by Leggett (1982) from DSDP Site 488 (Middle America Trench off Mexico, eastern Pacific Ocean).

Similar observations were provided by Leggett (1982) who described and categorized a series of disturbance features seen during DSDP Leg 66 in ascending order of severity, namely bowed laminations (where original sedimentary laminations are deflected downward), drilling laminations which are not sedimentary but caused by maceration of the rock and "are generally spaced with extreme regularity (2$4 \mathrm{~cm}$ )" (Leggett, 1982, p. 531), drilling biscuits which are discrete blocks of sediment of unequivocal mechanical origin with injected mud in between and which show circular striae on their tops and bottoms, core discs which are similar but more severely disturbed with eroded edges, and drilling breccia where chunks of broken up and disoriented core sit in a soupy matrix. An example of a disced core from Leggett (1982) is reproduced in Fig. 2b, and the classification of Leggett of the disturbance effects is reproduced in Fig. 3. We prefer the term core discing to encompass both the biscuits and core discs of Leggett's (1982) classification, to reflect Kidd's (1978) prior usage, and because biscuits are known as cookies in some parts of the English-speaking world. The phenomenon has also been called "core dicing" by Aziz et al. (2008b).

As noted by Kidd (1978) and Leggett (1982), drilling slurry can be injected between the core discs, resulting in thin partings and hence layering. Figure 4 (reproduced from Pearson and Nicholas, 2014) shows their explanation of the core discing (which they called biscuiting), as observed in a core from Eocene clays of Tanzania (Tanzania Drilling Project Site 2; Pearson et al., 2004). The same interval was later re-drilled and proved to be massive mudstone with no layers (Tanzania Drilling Project Site 20; Nicholas et al., 2006). Pearson and Nicholas (2014) argued that the observed discs in the Tanzanian core are similar in appearance to the 
A

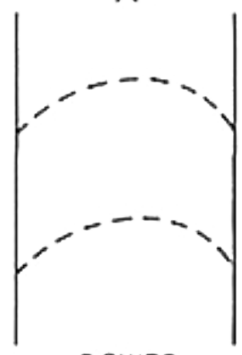

BOWED LAMINATIONS

Limited to uncon. solidated mud in upper cores.
B

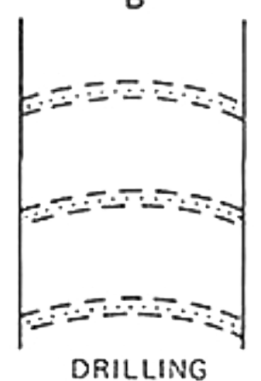

LAMINATIONS

Laminations darker. finer grained than intervening material, but of same con. sistency.
C

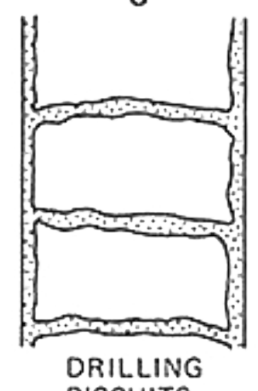

BISCUITS

Laminations, which may or may not be continuous with smears along core liners, are softer than intervening material (biscuits).
D

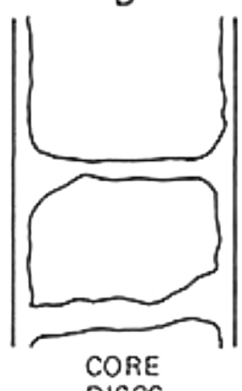

DISCS

Discrete, isolated discs of lithified material, \pm a sep arating soupy matrix: corners of discs may be missing.

Figure 3. "Types of drilling deformation in Leg 66 cores" reproduced with caption from Leggett (1982).

layering in the Millville and Wilson Lake B cores; hence, they suggested those cores too are disced.

Core discing is especially a problem when swelling clays are drilled because these expand in contact with water and can cause high pressure around the bit. Pearson and Nicholas (2014) pointed out that overpressure in the hole at Millville had been reported at the time by the drilling engineer, that the recovered sediment was more than the interval drilled (which is consistent with mud injection, although core expansion can have other causes), and that injection of slurry into the formation had been noted (see "Operations" in Sugarman et al., 2005). Moreover, sediment loggers repeatedly suggested that the layering in the cores might be artificial (see core description sheets 91, 103, 108, 121, and 139 in Sugarman et al., 2005). Pearson and Nicholas (2014) suggested that close observation of Millville and Wilson Lake B might confirm that the disputed layers are core discs, that is, that a "tell-tale feature of this kind of disturbance is that spinning of the biscuits can leave concentric grooves on the contacts with the partings" (Pearson and Nicholas, 2014).

In response to Pearson and Nicholas (2014) and the other comments (Stassen et al., 2014; Zeebe et al., 2014), Wright and Schaller (2014) acknowledged that mud injection may have occurred at Millville but rejected it as a general explanation for the layers in the Marlboro clay on two main grounds: that no overpressure had been reported when Wilson Lake B was drilled, and that layering had also been observed at an outcrop exposure at Medford, New Jersey (which we discuss further below). Furthermore, they suggested that "injection and discing during coring generally follow pre-existing zones of weakness, here provided by rhythmic sandy-silt beds observed in outcrop".

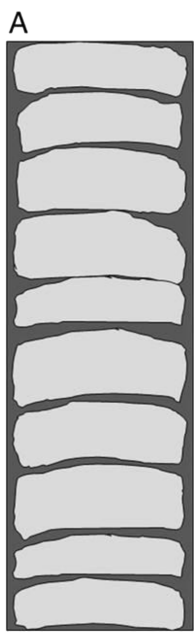

CARTOON

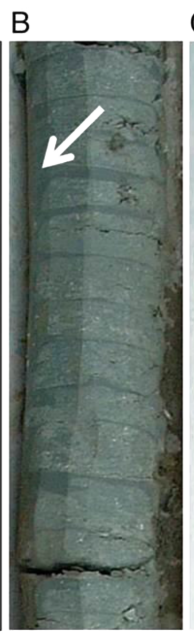

TANZANIA

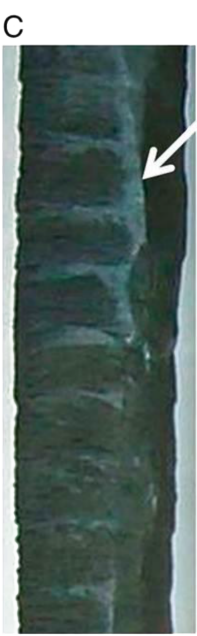

MILLVLLE

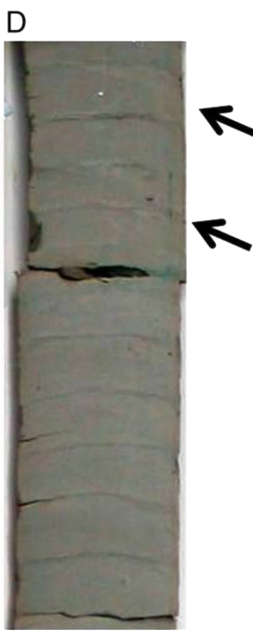

WILSON LAKE B
Figure 4. “(a) Conceptual model of biscuiting caused by drilling disturbance. (b) Detail of Tanzania Drilling Project Site 2 (Pearson et al., 2004). (c) Detail of the Millville core (modified from Wright and Schaller, 2013). (d) Detail of the Wilson lake B core (modified from Wright and Schaller, 2013). White arrows indicate continuity between the external drilling mud, now mostly scraped off in the Tanzania and Millville cores, and the thin partings between the biscuits. Dark arrows point at possible bedding at an angle to biscuiting." Reproduced with caption from Pearson and Nicholas (2014).

\section{New observations on the drill cores}

In order to resolve this debate, one of us (P. N. Pearson) made new observations on the cores at a visit to the Rutgers core repository on 19-21 March 2014. At that time he discussed the issues constructively with J. D. Wright and M. F. Schaller.

The Millville cores (Fig. 5) have oxidized, desiccated, and broken up (Fig. 5b), but the layering is still very clear, as are 

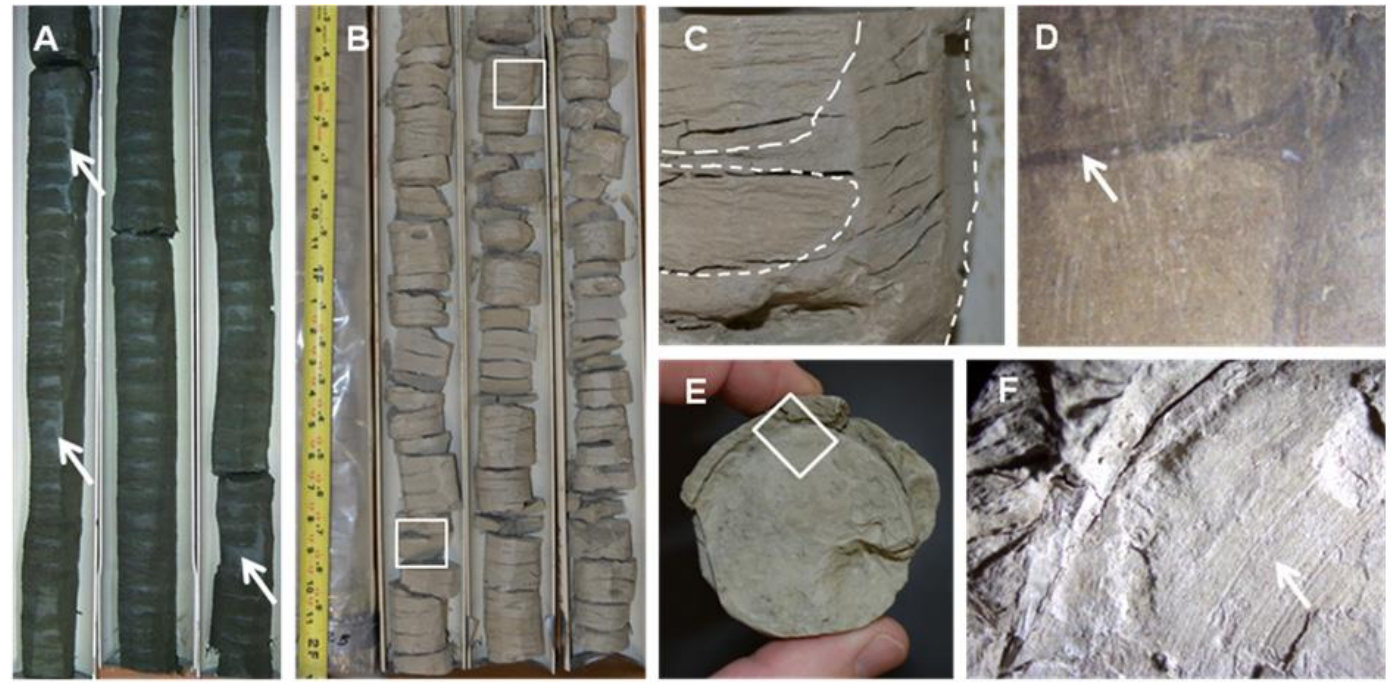

Figure 5. Evidence for drilling disturbance in the Millville core from the interval 890 to 910 feet subsurface $(1$ foot $=0.3048 \mathrm{~m})$. (a) Part of the core when freshly recovered (modified from Wright and Schaller, 2013, arrows added). The horizontal layers were described by Wright and Schaller (2013) as rhythmically bedded couplets, but were interpreted by Pearson and Nicholas (2014) as alternations of core discs and injected slurry. External drilling mud has been scraped off, but patches remain (as highlighted by arrows). Note that the thin internal partings are reflective like the external mud, and appear contiguous with it in places. (b) Part of the same core as viewed on 19 March 2014 after desiccation during nearly a decade of storage. Note that the core has fractured in many places along the slurry partings. (c) Detail of upper highlighted area in (b), showing a thick layer of external drilling mud still attached to the right hand side. (d) Part of the same interval now cut in half-round and viewed under the microscope. The drilling slurry (darker color) forms a thin parting through the centre of the core (highlighted with arrow) which is contiguous with the external mud. The core discs appear eroded at their edges. (e) Top surface of the core disc from the lower highlighted area in (b), showing an external coating of drilling mud around the upper half from the back of the core where it was not originally scraped off. (f) Microscopic detail of highlighted area in (e) showing the top surface of the core disc with concentric grooves, evidence of spinning in the core barrel. Similar observations were made at other levels in the core.

areas of superficial drilling mud. The latter is slightly darker in color even after desiccation, and has a swirly texture under a hand lens. Various features confirm that the prominent layering is drilling disturbance. Notable among these are (i) the characteristic length scale and regularity of the discing (Fig. 5a, b), (ii) physical continuity between the partings and external drilling mud of identical color and texture (Fig. 5c, d), (iii) widening of the partings toward the outer edge consistent with abrasion of the core discs (Fig. 5d), and (iv) concentric grooves on the surface of core discs (Fig. 5f).

Unlike Millville, the Wilson Lake B cores have been split into sampling and archive halves. New observations were made on the latter, including an interval of polished core surface originally made by Wright and Schaller (2013). Similar features to those in the Millville cores are evident, especially the concentric grooves on the surface of the core discs where they are in contact with the soft, injected drilling mud (Fig. 6a-d, which compares closely with the example illustrated by Kidd, 1978, reproduced in Fig. 1a). Also clearly visible on the polished surface is evidence for micro-fracturing of the formation at the edges of several of the core discs (Fig. 7a, b). The thin layers divide and expand around these fractures, giving proof of slurry intrusion. Hence, we conclude that Wilson Lake B was subject to the same type of drilling disturbance as Millville even if overpressure in the hole was not recorded at the time of drilling.

Both Millville and Wilson Lake B cores were scrutinized carefully for signs of bedding. Unfortunately, cores from both holes are now quite oxidized and their surfaces are covered with small gypsum crystals (presumably following oxidation of pyrite in contact with air), so although the sediments have a quasi-horizontal fabric, no clear evidence of compositionally distinct beds could be observed in cores from either hole.

The thicknesses of the core discs at Millville and Wilson Lake B are remarkably regular (for Millville, $1.9 \mathrm{~cm} \pm 0.8 \mathrm{~cm}$ at $1 \sigma$ as measured by Wright and Schaller, 2013), and similar to those observed by Kidd (1978) and Leggett (1982) and the Tanzanian core (see Fig. 4a). We suggest that the regularity has a mechanical origin related to the strength of the formation and the torque induced by the rotating bit, which in turn is related to the core diameter which determines the distance vector component of the torque. Failure of the core likely occurs at some threshold level of torque, and regular discing will result provided that the drilling rate is constant and the formation homogeneous. The existence of core discs at Wilson Lake B provides a possible explanation for apparent cyclicity in the bulk sediment oxygen 

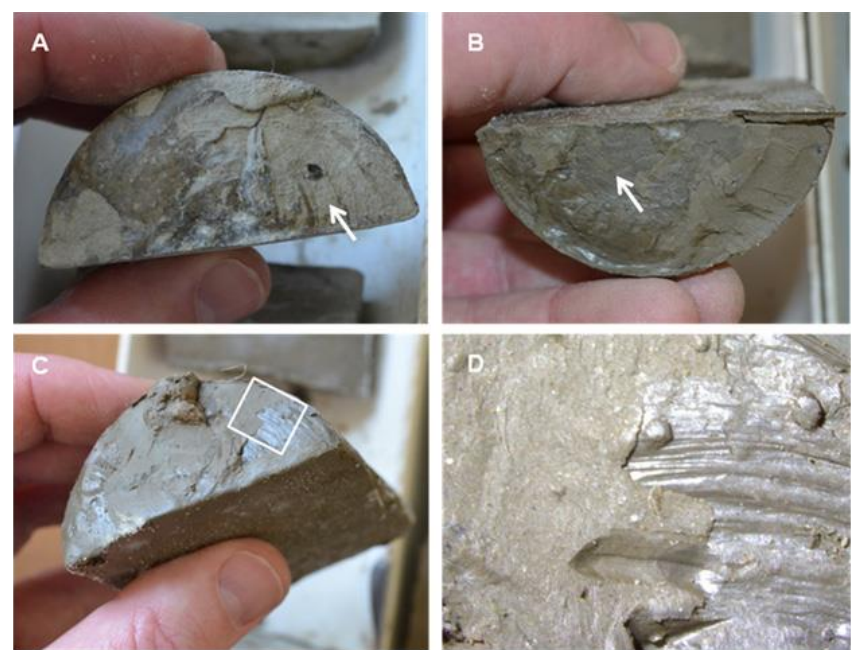

Figure 6. Concentric grooves in various parts of the Wilson Lake B core, as seen in half-round specimens from the archive half. (a) Top of a core disc with patches of adhering injected slurry and concentric grooves (highlighted with arrow). (b) Base of a core disc with patches of adhering injected slurry and concentric grooves (highlighted with arrow). (c) Top of a core disc with patches of adhering injected slurry and concentric grooves. (d) Microscopic detail of highlighted area in (c) showing a patch of remaining slurry (to the left) unconformably overlying the surface of a core disc which shows concentric grooves. Similar observations were made at other levels in the core.

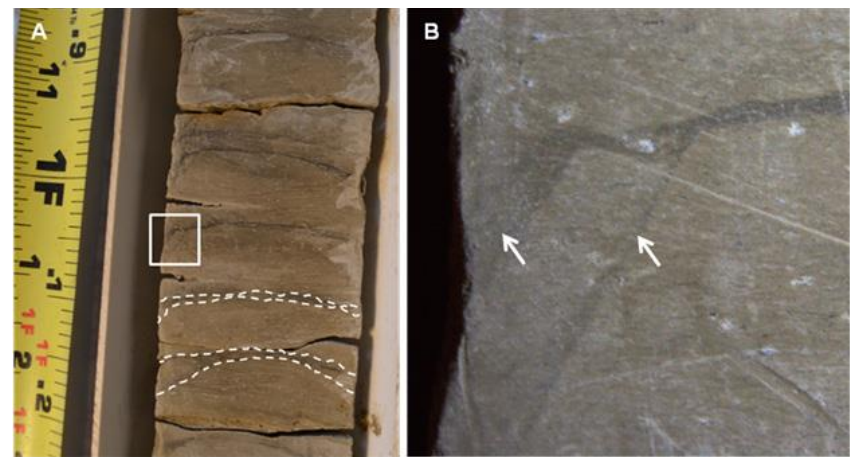

Figure 7. Evidence for drilling disturbance in the Wilson Lake B core; new photographs of part of a polished half-round interval prepared originally by Wright and Schaller (2013). (a) Alternating core discs and injected slurry, thickening to the edges (highlighted) with deformation features at the edge of the core. (b) Microscopic detail of highlighted area in (a) showing fractured (micro-faulted) core injected with drilling slurry (darker color, highlighted with arrow). Very similar fracturing features occur in the three overlying core discs in (a).

isotope ratios indicated by Wright and Schaller (2013): if some of the samples were contaminated by drilling slurry with a distinct isotopic signature, non-climatic variability in the $\delta^{18} \mathrm{O}$ might conceivably have been measured. However,

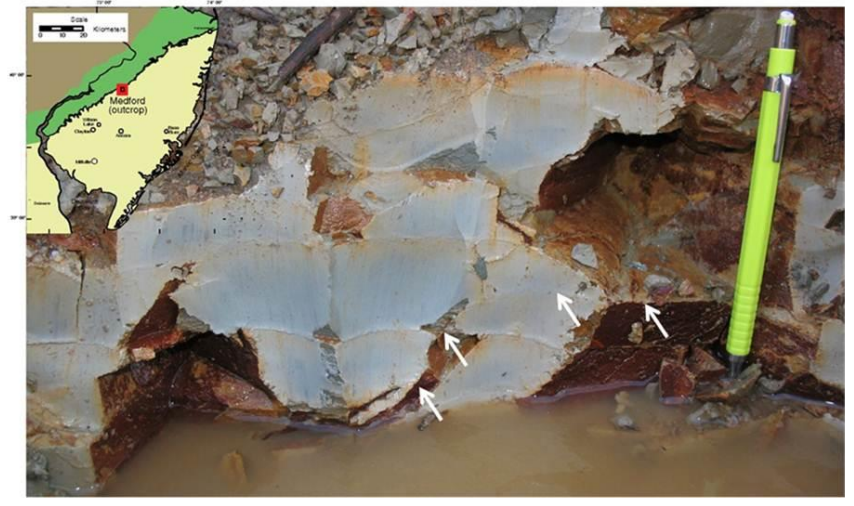

Figure 8. Photograph of Marlboro clay exposure reproduced and modified (arrows added) from Wright and Schaller (2014): "Photograph of the rhythmic bedding in the Marlboro clay exposed in the Rancocas Creek, Medford, NJ. Pencil is $\sim 15 \mathrm{~cm}$. ...The blue/gray clay is interrupted at regular ( $\sim 2 \mathrm{~cm}$ intervals) by very thinly bedded silts and very fine sands. These areas also provide zones of weakness along which fractures will form when hand samples from the exposures are dried in the laboratory" (caption from Wright and Schaller, 2014). In our interpretation, the photograph shows several examples where joint surfaces curve and intersect one another in a fish-scale type arrangement. This is seen, for example, in the surface that forms a ledge behind the pencil (highlighted with arrows). No clear sedimentary bedding is apparent.

we also note that the time series are relatively short and statistically significant cyclicity has not been demonstrated.

\section{Re-interpretation of the field photograph from Medford}

Wright and Schaller (2014) claimed that the Marlboro clay exhibits rhythmic layering in outcrop, which obviously can not be a drilling artifact. Their field photograph from Medford (which we reproduce here as Fig. 8) shows part of a small exposure at stream level that had been cleaned using vertical strikes of a cutting tool. The photograph was never intended as definitive evidence by itself (J. D. Wright and M. F. Schaller, personal communication, 2014), and further observations on the locality will hopefully shed more light on the sedimentology. The supposedly rhythmic layering in the photograph is picked out by quasi-horizontal features running across the surface of the exposure characterized in places by orange staining, small ledges, and subtle variations in the lightness of the clay. The vertical blows of the cutting tool have to some extent smeared features in the sediment downward, as picked out especially by vertical streaks in the orange staining.

We dispute that the photograph shows evidence of rhythmic layering comparable to that observed in the cores. Instead, we interpret the quasi-horizontal layers as joint surfaces along which oxidizing fluids have passed, causing the 
orange iron oxide staining and potentially introducing or concentrating silt particles along the joints. Oxidation may also have affected the immediately adjacent clay, lightening the color, although smearing on the vertical surface complicates the interpretation. Evidence that the layers are joints and not sedimentary partings is that they curve downward in places, intersecting one another. This interpretation is consistent with previous descriptions of the Marlboro clay as being massive in both outcrop and cores, with evidence of some irregular sedimentary layers (sand laminae and pods) or thin, sometimes discontinuous clay laminae in some intervals, but no reported rhythmicity (e.g., Clark and Miller, 1906; Reinhardt et al., 1980; Gibson and Bybell 1991; Kopp et al., 2009; Self-Trail et al., 2012).

\section{Foraminifer accumulation rates}

Pearson and Nicholas (2014) stressed that, notwithstanding the drilling disturbance, the Millville cores might provide some broad constraints on the duration of the CIE onset from foraminifer accumulation rates. Stassen et al. (2014) pointed out that sediment "accumulation rates of $\sim 2 \mathrm{~cm} \mathrm{yr}^{-1}$ are highly improbable because of the micro-fossil content", especially the presence of symbiont-bearing planktonic foraminifera which only thrive in relatively open ocean environments with sufficient light intensity. To this can be added the observation that photosynthesizing calcareous nannofossils are also common at all New Jersey PETM drill sites (e.g., Gibson et al., 1993; Gibbs et al., 2006; Self-Trail et al., 2012). A possible modern analogue of the sort of environmental setting proposed by Wright and Schaller (2014) for the Marlboro clay is the muddy and fast-sedimenting Long Island Sound estuary (Lopez et al., 2014), with water depths of $\sim 40 \mathrm{~m}$. But here light penetration is less than $5 \mathrm{~m}$ and both photosymbiotic planktonic foraminifera and calcareous nannoplankton are absent (Lopez et al., 2014). In general, planktonic foraminifera are absent in mud-belt sediments deposited on the shelf (Cattaneo et al., 2004) including on the Amazon River shelf at depths $<100 \mathrm{~m}$, where benthic but no planktonic foraminifera have been recorded (Vilela, 2003).

Wright and Schaller (2014) reported concentrations of total (benthic plus planktonic) foraminifera in the $>100 \mu \mathrm{m}$ size range for the Wilson Lake B core ranging from $\sim 150$ to 350 individuals per gram of sediment. The percentage of planktonic foraminifera in PETM sediments in various New Jersey core sites is generally $65-80 \%$ (Gibson et al., 1993; Stassen et al., 2012). If the layers were annual, this figure would imply extremely high rates of accumulation of both benthic and planktonic foraminifera. Wright and Schaller (2014) stated that this reflects a production of approx. $1 \times 10^{6}$ specimens per $\mathrm{m}^{2}$ per year but did not document how they arrive at this estimate. We offer the following approximate calculation: if we take a roughly average figure of 200 specimens per gram (Stassen et al., 2012; Wright and
Schaller, 2014) and a dry bulk density of 1.4 (typical for mudrocks at the quoted burial depth; Bryant et al., 1981), this will equate to 280 specimens per $\mathrm{cm}^{3}$. The supposedly annual layers at Wilson Lake B are $2.5 \mathrm{~cm}$ thick; hence, this indicates 700 specimens per $\mathrm{cm}^{2}$ per year, or $7 \times 10^{6}$ specimens per $\mathrm{m}^{2}$ per year. This is much higher than the estimate of Wright and Schaller (2014), but even that exceeds known accumulation rates for both planktonic and benthic foraminifera (Zaric et al., 2006). Hence, we suggest that the micropaleontology (both the abundance of specimens and the abundance of photosymbiotic foraminifera and calcareous nannoplankton) shows that the onset of the CIE at Millville likely represents thousands of years, not years, which would effectively rule out an instantaneous cause such as comet impact.

\section{Conclusions}

New observations confirm that the prominent rhythmic couplets in the Millville and Wilson Lake B cores are caused by drilling disturbance and are not original sedimentary features. We cannot rule out the possibility that some of the fracturing may have occurred along pre-existing bedding planes, although we found no evidence of that having occurred, despite careful observation of the cores. Hence, there is no evidence that the Marlboro clay is rhythmically layered, and no support for the short chronology of the onset to the PETM suggested by Wright and Schaller (2013). Nevertheless, the record presented by Wright and Schaller (2013) from Millville is clearly important, potentially the best-resolved marine record of the CIE onset yet published, with fine detail including possible pulses and even a hint of cyclicity. In our interpretation, foraminifer accumulation rates point to a longduration onset lasting $>1 \mathrm{kyr}$, but because the Millville core is much disturbed by injected drilling slurry and the critical interval has been heavily sampled, re-drilling and renewed investigation of the locality should be a high priority.

Acknowledgements. We thank K. Miller for access to the as yet unpublished Wilson Lake B core. We are very grateful to J. D. Wright and M. F. Schaller for the open and constructive manner in which they have cooperated with our research. We expected nothing less but it was very gratifying nonetheless, and to J. Browning for providing assistance to our investigation at the Rutgers core laboratory. Thanks also to Wright, Schaller, and C. Lombardi for organizing and participating in a constructive day in the field. This research, including rapid response travel funds, was supported by the UK Ocean Acidification Research Program and NERC grant NE/H017518/1 to PNP.

Edited by: Y. Godderis 


\section{References}

Aze, T., Pearson, P. N., Dickson, A. J., Badger, M. P. S., Bown, P. R., Pancost, R. D., Gibbs, S. J., Huber, B. T., Leng, M. J., Coe, A. L., Cohen, A. S., and Foster, G. L.: Extreme warming of tropical waters during the Paleocene-Eocene Thermal Maximum, Geology, 42, 739-742, 2014.

Aziz, H. A., Hilgen, F. J,.van Luijk, G. M., Sluijs, A., Kraus, M. J., Pares, J. M., and Gingerich, P. D.: Astronomical climate control on paleosol stacking patterns in the upper Paleocene-lower Eocene Willwood Formation, Bighorn Basin, Wyoming, Geology, 36, 531-534, 2008a.

Aziz, H. A., Di Stefano, A., Foresi, L. M., Hilgen, F. J., Iaccarino, S. M., Kuiper, K. F., Lirer, F., Salvatorini, G., and Turco, E.: Integrated stratigraphy and 40Ar/39Ar chronology of early Middle Miocene sediments from DSDP Leg 42A, Site 372 (Western Mediterranean). Palaeogeography, Palaeoclimatology, Palaeoecology, 257, 123-138, 2008b.

Bown, P. R. and Pearson, P. N.: Calcareous plankton evolution and the Paleocene/Eocene thermal maximum event; new evidence from Tanzania, Mar. Micropal., 71, 60-70, 2009.

Bralower, T. J., Thomas, D. J., Zachos, J. C., Hirschmann, M. M., Röhl, U., Sigurdsson, H., Thomas, E. and Whitney, D. L.: Highresolution records of the late Paleocene thermal maximum and circum-Caribbean volcanism: is there a causal link?, Geology, 25, 963-966, 1997.

Bryant, W. R., Bennett, R., and Katherman, C.: Shear strength, consolidation, porosity, and permeability of oceanic sediments, in Emiliani, C. (ed.) The Sea, vol. 7, John Wiley, New York, 15551616, 1981.

Cande, S. C. and Kent, D. V.: Revised calibration of the geomagnetic polarity timescale for the Late Cretaceous and Cenozoic, J. Geophys. Res., 100, 6093-6095, 1995.

Cattaneo, A., Trincardi, F., Langone, L., Asioli, A., and Ouig, P.: Clinoform generation on Mediterranean margins, Oceanography, 17, 105-117, 2004.

Clark, W. B.,and Miller, B. L.: Clay deposits of the Virginia coastal plain. Virginia Geol. Surv. Bull., 2, 11-24, 1906.

Cramer, B. S. and Kent, D. V.: Bolide summer: The Paleocene/Eocene thermal maximum as a response to an extraterrestrial trigger, Palaeogeog., Palaeoclimatol., Palaeoecol., 224, 144166, 2005.

Cui, Y., Kump, L. R., Ridgwell, A. J., Charles, A. J., Junium, C. K., Diefendorf, A. F., Freeman, K. H., Urban, N. M., and Harding, I. C.: Slow release of fossil carbon during the Palaeocene - Eocene Thermal Maximum, Nat. Geosci., 4, 481-485, 2011.

Deconto, R. M., Galeotti, S., Pagani, M., Tracy, D., Schaefer, K., Zhang, T., Pollard, D., and Beerling, D .J.: Past extreme warming events linked to massive carbon release from thawing permafrost, Nature, 485, 87-92, 2012.

Dickens, G. R., O’Neil, J. R., Rea, D. K. and Owen, R. M.: Dissociation of oceanic methane hydrate as a cause of the carbon isotope excursion at the end of the Paleocene, Paleoceanography, 10, 965-971, 1995.

Dunkley Jones, T., Ridgwell, A., Lunt, D. J., Maslin, M. A., Schmidt, D. N., and Valdes, P. J.: A Paleogene perspective on climate sensitivity and methane hydrate instability, Phil. Trans. Roy. Soc. A, 368, 2395-2415, 2010.

Eldholm, E. and Thomas, E.: Environmental impact of volcanic margin formation, Earth Planet. Sci. Lett., 117, 319-329, 1993.
Gibbs, S. J., Bralower, T. J., Bown, P. R., Zachos, J. C., and Bybell, L. M.: Shelf and open-ocean calcareous phytoplankton assemblages across the Paleocene - Eocene Thermal Maximum: Implications for global productivity gradients, Geology, 34, 233-236, 2006.

Gibson, T. G. and Bybell, L. M. (eds): Paleocene-Eocene Boundary sedimentation in the Potomac River Valley, Virginia and Maryland, I.G.B.P. Project 308, Field Trip Guidebook, 1-13, 1991.

Gibson, T. G., Bybell, L. M., and Owens, J. P.: Latest Paleocene lithologic and biotic events in neritic deposits of southwestern New-Jersey, Paleoceanography, 8, 495-514, 1993.

Graber, K. K., Pollard, E., Jonasson, B., and Schulte, E. (Eds): Overview of Ocean Drilling Program engineering tools and hardware, Proc. ODP, Technical Note, 31, doi:10.2973/odp.tn.31.2002, 2002.

Harris, A. D., Miller, K. G., Browning, J. V., Sugarman, P. J., Olsson, R. K., Cramer, B. S., and Wright, J. D.: Integrated stratigraphic studies of Paleocene - lowermost Eocene sequences, New Jersey Coastal Plain: Evidence for glacioeustatic control, Paleoceanography, 25, PA3211, doi:10.1029/2009PA001800, 2009.

Higgins, J. A. and Schrag, D. P.: Beyond methane: towards a theory for the Paleocene - Eocene thermal maximum. Earth Planet. Sci. Lett., 245, 523-537, 2006.

Hönisch, B., Ridgwell, A., Schmidt, D., Thomas, E., Gibbs, S. J., Sluijs, A., Zeebe, R., Kump, L., Martindale, R. C., Greense, S. E., Kiessling, W., Ries, J., Zachos, J. C., Royer, D., Barker, S., Marchitto, T. M., Moyer, R., Pelejero, C., Ziveri, P., Foster, G. L., and Williams, B.: The Geological Record of Ocean Acidification, Science, 335, 1058-1963, 2012.

Hubbard, J.: Biscuit with your tea?, ARISE (Andrill Research Immersion for Science Educators) blog post, http://arise-in-antarctica.blogspot.co.uk/2007/11/ biscuit-with-your-tea.html (last acess: 30 April 2014), 2007.

Huber, M.: A hotter greenhouse?, Science, 321, 353-354, 2008.

Katz, M. E., Pak, D. K., Dickens, G. R., and Miller, K. G.: The source and fate of massive carbon input during the latest Paleocene thermal maximum, Science, 286, 1531-1533, 1999.

Kemp, A. E. S.: Evidence for abrupt climate changes in annually laminated sediments, Phil. Trans. R. Soc. Lon. A., 361, 18511870, 2003.

Kennett, J. P. and Stott, L. D.: Abrupt deep-sea warming, palaeoceanographic changes and benthic extinctions at the end of the Paleocene, Nature, 353, 225-229, 1991.

Kent, D. V., Cramer, B. S., Lanci, L., Wang, D., Wright, J. D., and van der Voo, R.: A case for a comet impact trigger for the Paleocene/Eocene thermal maximum and carbon isotope excursion, Earth Planet. Sci. Lett., 211, 13-26, 2003.

Kidd, R. B.: Core-discing and other drilling effects in DSDP Leg 42A Mediterranean sediment cores. Init. Repts. DSDP, 42, 11431149, 1978.

Kopp, R. E., Schumann, D., Raub, T. D., Powars, D. S., Godfrey, L. V., Swanson-Hysell, N. L., Maloof, A. C., and Vali, H.: An Appalachian Amazon?, Magnetofossil evidence for the development of a tropical river-like system in the mid-Atlantic United States during the Paleocene-Eocene thermal maximum, Paleoceanography, 24, PA4211, doi:10.1029/2009PA001783, 2009.

Kurtz, A. C., Kump, L. R., Arthur, M. A., Zachos, J. C., and Paytan, A.: Early Cenozoic decoupling of the global 
carbon and sulfur cycles, Paleoceanography, 18, PA1090, doi:10.1029/2003PA000908, 2003.

Leggett, J. K.:Drilling induced structures in Leg 66 sediments, Init. Repts. DSDP 66, 531-535, 1982.

Lopez, G., Carey, D., Carlton, J.T., Cerrato, R., Dam, H., DiGiovanni, R., Elphick, C., Frisk, M., Gobler, C., Hice, L., Howell, P., Jordaan, A., Lin, S., Liu, S., Lonsdale, D., McEnroe, M., McKown, K., McManus, G., Orson, R., Peterson, B., Pickerell, C., Rozsa, R., Shumway, S., Siuda, A., Streich, K., Talmage, S., Taylor, G., Thomas, E., Van Patten, M., Vaudrey, J., Yarish, C., Wikfors, G., and Zajac, R.: Chapter 6: Biology and Ecology of Long Island Sound, in: Long Island Sound, Prospects for the Urban Sea, Springer Series on Environmental Management, 285-479, 2014.

McInerney, F. A. and Wing, S. L.: The Paleocene-Eocene thermal maximum: A perturbation of the carbon cycle, climate, and biosphere with implications for the future, Ann. Rev. Earth Plan. Sci., 39, 489-516, 2011.

Nicholas, C. J., Pearson, P. N., Bown, P. R., Dunkley Jones, T., Huber, B. T., Karega, A., Lees, J. A., McMillan, I. K., O’Halloran, A., Singano, J. M., and Wade, B. S.: Stratigraphy and sedimentology of the Upper Cretaceous to Paleogene Kilwa Group of Tanzania, J. Afr. Earth Sci., 45, 431-466, 2006.

Nisbet, E. G., Jones, S. M., Maclennan, J., Eagles, G., Moed, J., Warwick, N., Bekki, S., Braesicke, P., Pyle, J. A., and Fowler, C. M. R., Kick-staring ancient warming, Nat. Geosci., 2, 156-159, 2009.

Pearson, P. N. and Nicholas, C. J.: Layering in the Paleocene/Eocene boundary of the Millville core is drilling disturbance, Proc. Natl. Acad. Sci. USA, 111, E1064-E1065, 2014.

Pearson P. N., Nicholas C. J., Singano J. M., Bown P. R., Coxall H. K., van Dongen B. E., Huber B. T., Karega A., Lees J. A., Msaky, E., Pancost, R. D., Pearson, M., and Roberts, A. P.: Paleogene and Cretaceous sediment cores from the Kilwa and Lindi areas of coastal Tanzania: Tanzania Drilling Project Sites 1-5, J. Afr. Earth Sci., 39, 25-62, 2004.

Reinhardt, J., Newell, W. L., and Mixon, R. B.: Geology of the Oak Grove core, Virginia Division of Mineral Resources Publication, 20, 1-13, 1980.

Ridgwell A. and Schmidt, D. N.: Past constraints on the vulnerability of marine calcifiers to massive $\mathrm{CO}_{2}$ release, Nat. Geosci., 3, 196-200, 2010.

Self-Trail, J. M.., Powars, D. S., Watkins, D. K., and Wandless, G. A.: Calcareous nannofossil assemblage changes across the Paleocene-Eocene Thermal Maximum: Evidence from a shelf setting, Mar. Micropaleo., 92/93, 61-80, 2012.

Sluijs, A., Brinkhuis, H., Schouten, S., Bohaty, S. M., John, C. M., Zachos, J. C., Reichart, G.-J., Sinninge Damsté, J. S., Crouch, E. M., and Dickens, G. R.: Environmental precursors to rapid light carbon injection at the Palaeocene/Eocene boundary, Nature, 450, 1218-1225, 2007a.

Sluijs, A., Bowen, G. J., Brinkhuis, H., Lourens, L. J., and Thomas, E.: The Palaeocene-Eocene Thermal maximum super greenhouse: biotic and geochemical signatures, age models and mechanisms of climate change, in: Deep Time Perspectives on Climate Change: Marrying the Signal from Computer Models and Biological Proxies, edited by: Williams, M., Haywood, A. M., Gregory, F. J., and Schmidt, D. N., The Micropalaeontological
Society, Special Publications, The Geological Society, London, 323-351, 2007b.

Stassen, P., Thomas, E., and Speijer, R. P.: Integrated stratigraphy of the Paleocene-Eocene Thermal Maximum in the New Jersey Coastal Plain: towards understanding the effects of global warming in a shelf environment, Paleoceanography, 27, PA4210, doi:10.1029/2012PA002323, 2012.

Stassen, P., Speijer, R. P., and Thomas, E.: Unsettled puzzle of the Marlboro clays, Proc. Natl. Acad. Sci. USA, 111, E1066-E1067, 2014.

Storey, M., Duncan, R. A., and Swisher, C. C.: Paleocene-Eocene thermal maximum and the opening of the northeast Atlantic, Science, 316, 587-589, 2007.

Sugarman, P. J., Miller, K. G., Browning, J. V., McLaughlin, P. P., Brenner, G. J., Buttari, B., Cramer, B. S., Harris, A., Hernandez, J., Katz, M. E., Lettini, B., Misintseva, S., Monteverde, D. H., Olsson, R. K., Patrick, L., Roman, E., Wojtko, M. J., Aubry, M.-P., Feigenson, M. D., Barron, J. A., Curtin, S., Cobbs, G., Bukry, D., and Huffman, B. A.: Millville Site. Proc ODP, Init Repts, 174AX (Supplment), College Station, TX (Ocean Drilling Program), 1-94, 2005.

Svensen, H., Planke, S., Malthe-Sorenssen, A., Jamtveit, B., Myklebust, R., Eidem, T. R., and Rey, S. S.: Release of methane from a volcanic basin as a mechanism for initial Eocene global warming, Nature, 429, 542-545, 2004.

Thomas, C. D., Cameron, A., Green, R. E., Bakkenes, N., Beaumont, L. J, Collingham, Y. C., Erasmus, B. F. N., de Siqueir, M. F., Grainger, A., Hannah, L., Hughes, L., Huntley, B., van Jaarsveld, A. S., Midgley, G. F., Miles, L., Ortega-Huerta, M. A., Peterson, A. T., Phillips, O. L., and Williams, S. E.: Extinction risk from climate change, Nature, 427, 145-48, 2004.

Thomas, D. J., Zachos, J. C., Bralower, T. J., Thomas, E., and Bohaty, S.: Warming the fuel for the fire: evidence for the thermal dissociation of methane hydrate during the Paleocene-Eocene thermal maximum, Geology, 30, 1067-1070, 2002.

Thomas, E. and Shackleton, N. J.: The Paleocene-Eocene benthic foraminiferal extinction and stable isotope anomalies, in: Correlation of the Early Paleogene in Northwest Europe, edited by: Knox, R. W. O. B., Corfield, R., and Dunay, E. E., Geol. Soc. London, Spec. Pub., 101, 401-41, 1996.

Vilela, C. G.: Taphonomy of benthic foraminiferal tests of the Amazon shelf, J. Foramin. Res., 33, 132-143, 2003.

Wang, H., Kent, D. V., and Jackson, M. J.: Evidence for abundant isolated magnetic nanoparticles at the Paleocene-Eocene boundary, Proc. Natl. Acad. Sci. USA, 110, 25-430, 2013.

Wright, J. D. and Schaller, M. F.: Evidence for a rapid release of carbon at the Paleocene-Eocene thermal maximum, Proc. Natl. Acad. Sci. USA, 110, 15908-15913, 2013.

Wright, J. D. and Schaller, M. F.: Reply to Pearson and Nicholas, Stassen et al., and Zeebe et al.: Teasing out the missing piece of the PETM puzzle, Proc. Natl. Acad. Sci. USA, 111, E1068E1071, 2014

Zachos, J. C., Rohl, U., Schellenberg, S. A., Sluijs, A., Hodell, D. A., Kelly, D. C., Thomas, E., Nicolo, M., Raffi, I., Lorens, L. J., McCarren, H., and Kroon D.: Rapid acidification of the ocean during the Paleocene-Eocene Thermal Maximum, Science, 308, 1611-1615, 2005.

Zachos, J. C., Schouten, S., Bohaty, S., Quattlebaum, T., Sluijs, A., Brinhuis, H., Gibbs, S. J., and Bralower, T. J.: Extreme warming 
of mid-latitude coastal ocean during the Paleocene-30 Eocene Thermal Maximum: Inferences from TEX86 and isotope data, Geology, 34, 737-740, 2006.

Zachos, J. C., Bohaty, S. M., John, C. M., McCarren, H., Kelly, D. C., and Nielsen, T.: The Palaeocene-Eocene carbon isotope excursion: constraints from individual shell planktonic foraminifera records, Phil. Trans. R. Soc. A., 365, 1829-1842, 2007.
Zeebe, R. E., Dickens, G. R., Ridgwell, A., Sluijs, A., and Thomas, E.: Onset of carbon isotope excursion at the Paleocene-Eocene thermal maximum took millennia, not 13 years, Proc. Natl. Acad. Sci. USA, 111, E1062-E1063, 2014. 